\title{
Development and Evaluation of Potatoes Transgenic for a cry1Ac9 Gene Conferring Resistance to Potato Tuber Moth
}

\author{
Melanie M. Davidson, ${ }^{1}$ Jeanne M.E. Jacobs, Jill K. Reader, and Ruth C. Butler \\ New Zealand Institute for Crop \& Food Research Limited, Private Bag 4704, Christchurch, New Zealand \\ Christina M. Frater and Ngaire P. Markwick \\ Horticulture and Food Research Institute of New Zealand Limited, Private Bag 92169, Mt. Albert, \\ Auckland, New Zealand
}

\author{
Steve D. Wratten and Anthony J. Conner \\ Division of Plant, Soil and Ecological Sciences, Lincoln University, P.O. Box 84, Canterbury, New Zealand
}

\begin{abstract}
AdDITIONAL INDEX wORDs. Agrobacterium-mediated transformation, Bacillus thuringiensis, insect resistance, Phthorimaea operculella

Astract. Transgenic potato (Solanum tuberosum L.) lines of two cultivars, Ilam Hardy and Iwa, were developed using Agrobacterium-mediated transformation to transfer a cry1Ac9 gene under the transcriptional control of the CaMV 35S promoter. PCR confirmed the presence of the nptII selectable marker gene in all recovered lines. All ten lines of Ilam Hardy and 14 of 15 Iwa lines were PCR-positive for the cry gene. In greenhouse trials, all Ilam Hardy transgenic lines produced phenotypically normal plants and significantly inhibited larval growth of potato tuber moth (Phthorimaea operculella Zeller). In contrast, only $60 \%$ of the Iwa transgenic lines produced phenotypically normal plants, but all lines positive for the cry gene significantly inhibited larval growth. All transgenic lines with a greenhouse appearance equivalent to the nontransgenic controls and improved resistance to potato tuber moth larvae were planted in the field. Three of the ten Ilam Hardy lines and two of the eight Iwa lines retained phenotypically normal appearance in the field and produced tuber yields equivalent to the nontransgenic controls. All five of these transgenic lines significantly inhibited larval growth of potato tuber moth on excised field-grown leaves. A high correlation was established between larval growth indices from the greenhouse and the field. A transgenic line from each cultivar inhibited larval growth by over $40 \%$, and the line derived from Ilam Hardy prevented pupation of all larvae. Southern analysis on these five elite lines revealed that they contained either one or two copies of the cry1Ac9 gene. The amount of Cry protein in all transgenic lines tested was less than $60 \mathrm{ng} \cdot \mathrm{g}^{-1}$ of fresh leaf tissue. A transgenic line from each cultivar was identified with comparable phenotypic appearance and yield to their parent cultivars coupled with high resistance to PTM.
\end{abstract}

Potato tuber moth or PTM(Phthorimaea operculella Zeller) is one of the most economically damaging pests of potatoes (Solanum tuberosum $\mathrm{L}$.) in warm temperate and subtropical climates (Foot, 1979; Raman and Palacios, 1982; Siddig, 1988). Larvae mine into leaves and tubers in the field and into stored tubers. Mined tubers are unmarketable (Oatman and Platner, 1974). The mines also allow pathogens, such as fungi (e.g., Fusarium sp.) and bacteria (e.g., Erwinia sp.) entry into the tubers (Plaisted et al., 1994). Conventional management methods, such as the application of insecticides and cultural strategies could be augmented by the development of PTM resistant cultivars. However, attempts to develop resistant potato cultivars using traditional breeding methods have been unsuccessful (Chavez et al., 1989; Ortiz et al., 1989).

Gleave et al. (1992) cloned and sequenced a gene encoding a $133 \mathrm{kDa}$ Cry protein isolated from the Bacillus thuringiensis $(\mathrm{Bt})$ strain, DSIR732, serotyped as var. kurstaki. It has been designated cry1Ac9 (Crickmore et al., 1998). When expressed in Escherichia coli, the subsequent extract was shown to have insecticidal activity against PTM larvae (Gleave et al., 1992).

Received for publication 17 Jan. 2002. Accepted for publication 5 Apr. 2002. We thank Andrew Gleave for the binary vector, Sandra Martin for in vitro cultures of virus-free potato plants, and numerous people from Crop \& Food Research for their assistance in planting and harvesting the field trial. A Technology for Industry Fellowship from the Foundation for Research Science and Technology with Lincoln University and Alex McDonald (Merchants) Ltd provided financial support for M.M. Davidson.

${ }^{1}$ Corresponding author; email davidsonm@crop.cri.nz.
Beuning et al. (2001) modified this truncated version of cry1 Ac9 by introducing seven nucleotide changes into the coding sequence, which removed six potential poly(A) signals without altering the amino acid sequence. They cloned the 1.9-kb coding region into pART7, which placed the cry gene under the regulatory control of the $35 \mathrm{~S}$ promoter and the octopine synthase 3 , terminator. This chimeric gene was then removed as a 3.9-kb NotI fragment and ligated into the binary vector pART27 (Gleave, 1992), generating pART27cry 1 Ac9 $9^{\mathrm{B}}$. Feeding trials using PTM larvae on tobacco plants transgenic for this modified cry gene showed significantly lower growth, development and survival than larvae raised on the nontransgenic control (Beuning et al., 2001).

The purpose of this study was to transform this modified cry 1 Ac9 gene into potato, the main host of PTM. The putative transgenic plants were characterized using PCR and Southern analysis, and evaluated based on phenotypic appearance in the greenhouse and the field. Insect bioassays were conducted to determine the degree of resistance of transgenic lines to PTM larvae. The performance and yield of the transgenic lines was also evaluated in the field.

\section{Materials and Methods}

Plant material. Virus-free in vitro plants of Ilam Hardy and Iwa cultivars were micropropagated on a multiplication medium consisting of MS salts and vitamins (Murashige and Skoog, 1962) 
plus $30 \mathrm{~g} \cdot \mathrm{L}^{-1}$ sucrose, $40 \mathrm{mg} \cdot \mathrm{L}^{-1}$ ascorbic acid, $500 \mathrm{mg} \cdot \mathrm{L}^{-1}$ casein hydrolysate, and $7 \mathrm{~g} \cdot \mathrm{L}^{-1}$ agar.

DeVelopment of TRANSGENIC Plants. A. tumefaciens strain LBA4404 (Hoekema et al., 1983) harboring the binary vector pART27cry $1 \mathrm{Ac}^{\mathrm{B}}$ (Beuning et al., 2001), was incubated overnight in $\mathrm{LB}$ medium plus $300 \mathrm{mg} \cdot \mathrm{L}^{-1}$ spectinomycin at $23{ }^{\circ} \mathrm{C}$ on a shaking table. Fully expanded leaves from virus-free in vitro plants of Iwa and Ilam Hardy cultivars were excised, cut in half (15 to $20 \mathrm{~mm}^{2}$ explants), and then dipped in the Agrobacterium suspension for $\approx 30 \mathrm{~s}$. They were then blotted dry on sterilized filter paper (Whatman No. 1, $100 \mathrm{~mm}$ diameter) and cultured on potato callusing medium (multiplication medium supplemented with $0.2 \mathrm{mg} \cdot \mathrm{L}^{-1} \mathrm{NAA}$ and $2 \mathrm{mg} \cdot \mathrm{L}^{-1} \mathrm{BAP}$ ). After $2 \mathrm{~d}$ on the callusing medium, they were transferred to the same medium supplemented with Timentin $\left(200 \mathrm{mg} \cdot \mathrm{L}^{-1}\right)$, to inhibit overgrowth by the Agrobacterium cells. Five days later they were transferred to callusing medium containing Timentin $\left(200 \mathrm{mg} \cdot \mathrm{L}^{-1}\right)$ and kanamycin $\left(50 \mathrm{mg} \cdot \mathrm{L}^{-1}\right)$ to select for transformed cell colonies. Kanamycin-resistant cell colonies were subcultured onto regeneration medium (multiplication medium plus $1 \mathrm{mg} \cdot \mathrm{L}^{-1}$ zeatin and $5 \mathrm{mg} \cdot \mathrm{L}^{-1} \mathrm{GA}_{3}$ ) also supplemented with $200 \mathrm{mg} \cdot \mathrm{L}^{-1}$ Timentin and $50 \mathrm{mg} \cdot \mathrm{L}^{-1} \mathrm{kanamycin}$. When a shoot regenerated from a cell colony and grew to $\geq 5 \mathrm{~mm}$, it was transferred to multiplication medium containing Timentin $\left(200 \mathrm{mg} \cdot \mathrm{L}^{-1}\right)$ for micropropagation. To confirm kanamycin resistance in the resulting plants, shoots were subcultured onto medium containing Timentin and kanamycin $\left(50 \mathrm{mg} \cdot \mathrm{L}^{-1}\right)$, to eliminate any escapes by the lack of root formation. Putative transgenic plants were transferred back to the multiplication medium containing only Timentin to clonally propagate plants from each independently derived line.

All the independently derived lines that initiated roots on selection (kanamycin) media were transferred to a containment greenhouse and grown as previously described (Conner et al., 1994). Four replicate plants were established for each independently derived line and maintained in a containment greenhouse unit with a 20 to $27^{\circ} \mathrm{C}$ temperature range and a 16-h photoperiod. Tissue culture derived plants of the parent cultivars, Iwa and Ilam Hardy, were planted in the greenhouse at the same time, with a total of 21 replicate plants for the former and four replicate plants for the latter cultivar.

Screening of PUtative transformants using PCR. Total genomic DNA from leaf tissue of in vitro plants was extracted based on the method described by Bernatzky and Tanksley (1986). The lines were tested by PCR for the presence of the cry 1 Ac9 gene and the nptII gene. PCR reactions were carried out in a Mastercycler (Eppendorf, Hamburg, Germany). The PCR reactions included $2.5 \mu \mathrm{L} 10 \times$ buffer $(750 \mathrm{~mm}$ Tris- $\mathrm{HCl}(\mathrm{pH} 8.8)$, $200 \mathrm{~mm}\left(\mathrm{NH}_{4}\right)_{2} \mathrm{SO}_{4}, 0.1 \%$ (v/v) Tween 20), $1.5 \mu \mathrm{L} 25 \mathrm{~mm} \mathrm{MgCl}_{2}$, $2.5 \mu \mathrm{L}$ dNTP (at 2 mM each of dATP, dCTP, dGTP, dTTP), 0.25 $\mu \mathrm{L}$ Red Hot DNA polymerase at $5 \mathrm{U} / \mu \mathrm{L}$ (Advanced Biotechnologies, Surrey, U.K.), $1.0 \mu \mathrm{L}$ of each of the forward and reverse primers (at $10 \mu \mathrm{M}$ ), $1.0 \mu \mathrm{L}$ of DNA (10 to $50 \mathrm{ng}$ ) and water to a total volume of $25 \mu \mathrm{L}$. For the cry gene the PCR profile was $1 \mathrm{~min}$ $93^{\circ} \mathrm{C}$, followed by 35 cycles of [ $30 \mathrm{~s} 92^{\circ} \mathrm{C}, 30$ s $58^{\circ} \mathrm{C}, 90 \mathrm{~s} 72^{\circ} \mathrm{C}$ ], finishing with $6 \mathrm{~min} 72^{\circ} \mathrm{C}$. The nucleotide sequences of the primers were 5'-CAGTCTAGAAGACCAAAGGG-3' (ex 35S promoter) and 5'-CGCAATTGTTTGTTATTGTGGCG-3' (ex ocs 3' terminator), which generate an expected PCR product of $2600 \mathrm{bp}$. For the $n p t \mathrm{II}$ gene the PCR profile was 1 min $93^{\circ} \mathrm{C}$ followed by 35 cycles of [30 s $\left.92{ }^{\circ} \mathrm{C}, 30 \mathrm{~s} 60{ }^{\circ} \mathrm{C}, 90 \mathrm{~s} 72^{\circ} \mathrm{C}\right]$, finishing with $6 \mathrm{~min} 72^{\circ} \mathrm{C}$. The primer sequences were 5'ATGACTGGGCACAACAGACCATCGGCTGCT-3' and 5'-
CGGGTAGCCAACGCTATGTCCTGATAGCGG-3', which generate an expected PCR product of $612 \mathrm{bp}$.

Southern ANALYSIS. Digestions of genomic DNA were performed using HindIII (NEB, Beverly, M.A.) at 5 units per $\mu \mathrm{g}$ DNA. HindIII restricts once within the T-DNA of pART27 cry $1 \mathrm{Ac} 9^{\mathrm{B}}$. About $10 \mu \mathrm{g}$ of restricted DNA was loaded per lane on a $0.8 \%$ TAE-buffered agarose gel. Following separation of fragments, the DNA was transferred to Hybond $\mathrm{N}+$ membrane (Amersham, Little Chalfont, U.K.). Hybridization was performed using a fragment from the chimeric cry gene that was radiolabelled using the Megaprime DNA labelling system (Amersham, Little Chalfont, U.K.). Membranes were placed on Kodak XOmat X-ray film (Eastman Kodak Company, Rochester, N.Y.) for 1 to $5 \mathrm{~d}$.

ENZYME-LINKED IMMUNOSORBENT ASSAY (ELISA). A Cry1Ab/ Cry1 Ac Microwell Plate Kit (EnviroLogix Inc., Portland, Maine) was used. This kit represents a double-antibody sandwich quantitative ELISA with a detection limit of $1.2 \mu \mathrm{g} \cdot \mathrm{L}^{-1}$ for Cry $1 \mathrm{Ac}$ in sample extracts, using the equivalent Cry1 Ac calibrators of 1.5, 10 and $25 \mu \mathrm{g} \cdot \mathrm{L}^{-1}$. The spectrophotometric measurements were made with a microplate reader (ThermoMax; Molecular Devices, Sunnyvale, Calif.) at $450 \mathrm{~nm}$. The levels of Cry1 Ac protein in the leaf extracts were determined by extrapolation to a standard curve based on sample and standard absorbance values.

Phthorimaea operculella REARING. The insects used in the bioassays were obtained from a laboratory colony (established from a wild population from Pukekohe, New Zealand). The colony was maintained in a controlled temperature room at $22{ }^{\circ} \mathrm{C}$ with a $3{ }^{\circ} \mathrm{C}$ range, and under a photoperiod of $16 \mathrm{~h}$ light: $8 \mathrm{~h}$ dark. The rearing units were $29 \times 20 \times 13 \mathrm{~cm}$ transparent plastic containers, with $600 \mathrm{~mL}$ of Vermiculite covering the base, on top of which were placed six to eight large ( $>100 \mathrm{~g}$ ) tubers, punctured to facilitate PTM larval entry, which increases survival of the larvae (Fenemore, 1980). Neonate larvae were placed on the punctured tubers and the containers were covered with a fine Terylene mesh. When adults emerged (approximately three weeks later) filter paper moistened in a 5\% sugar solution was placed on the mesh. Female moths laid their eggs on the filter paper, through the mesh. The filter papers were replaced every $3 \mathrm{~d}$. The egg-laden papers were placed in sealed plastic container until eclosion from the egg, and then the rearing cycle was repeated.

INSECT FEEDING ASSAYS USING GREENHOUSE-GROWN PLANTS. Three weeks after planting the transgenic lines and nontransgenic controls in a containment greenhouse unit with a 20 to $27{ }^{\circ} \mathrm{C}$ temperature range and 16-h photoperiod, plants were placed individually into ventilated acetate containers $(220 \mathrm{~cm}$ diameter and $300 \mathrm{~mm}$ height). Batches of five neonate larvae were weighed (individual neonate larvae could not be accurately weighed at the balance limit of $10 \mu \mathrm{g}$ ) and then placed on each of the four replicate plants for the transgenic lines or nontransgenic plants. There were four replicate plants of the Ilam Hardy control and a total of 21 replicate plants for the Iwa control. After 9 d larvae recovered from the plants were reweighed together. Under the greenhouse conditions larvae on the control plants began to pupate after $9 \mathrm{~d}$. A growth index (GI) was calculated for each plant as $\log _{\mathrm{e}}$ (mean final weight/mean initial weight). The mean final weight was the weight of surviving larvae. The mean initial weight was the mean of five larvae placed on the plants at the beginning of the bioassays.

Agronomic evaluation of Field-grown plants. The transgenic lines that produced phenotypically normal plants and significantly inhibited PTM larval growth in the greenhouse were 


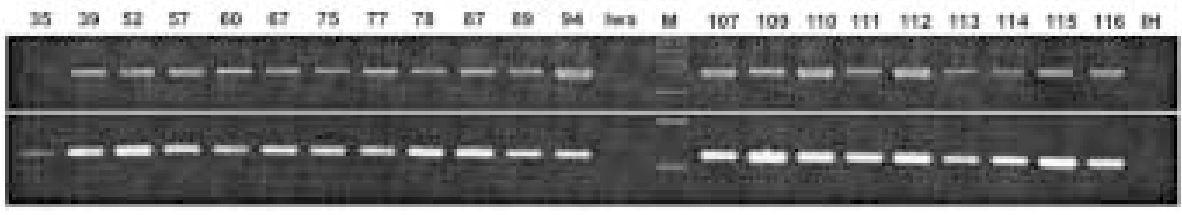

with analysis of variance (ANOVA) for all the data combined from both cultivars. The data from the field trial was initially examined with residual maximum likelihood (REML) methods (Gilmour et al., 1995) to assess whether there were significant con-

Fig. 1. PCR analysis of putative transgenic lines. The lanes labelled Iwa and IH (Ilam Hardy) represent parental nontransgenic cultivars, M represents the 500 bp molecular ruler 170-8203 (Bio-Rad Laboratories, Hercules, Calif.) size marker, and all other lanes confirm the transgenic status of representative lines with the presence of the cry gene with a 2600-pb fragment (top) and $n p t I I$ gene with a 612-pb fragment (bottom).

established in a field trial. This field trial was approved by the New Zealand 'Interim Assessment Group', an advisory committee of the Ministry for the Environment, on 24 Nov. 1997. The trial was planted on 12 Dec. 1997. Ten tubers derived from greenhouse grown plants of each transgenic or nontransgenic line were planted within a row $0.3 \mathrm{~m}$ apart in small plots, separated by $1 \mathrm{~m}$ within rows $0.75 \mathrm{~m}$ apart. Three replicate control plots of Iwa and two replicate control plots of Ilam Hardy were planted randomly among single plots of the transgenic lines. Plants were evaluated on the basis of foliage growth 8 to 12 weeks after planting using the categories: phenotypically normal; marginal leaf curl; leaf wrinkling; reduced vigor; and/or stunted plants, chlorosis and/or necrosis of leaves, and spindly appearance of shoots. A second area adjacent to the one described above was planted using an identical design and was treated with the organophosphate insecticide Disyston (a.i. disulfoton, $100 \mathrm{~g} \cdot \mathrm{kg}^{-1}$ ) to provide a comparison between a conventionally controlled block with the transgenic lines. The insecticide was applied in a band of granules along the base of the furrows at planting at the recommended rate of $20 \mathrm{~kg} \cdot \mathrm{ha}^{-1}$. Three buffer rows of nontransgenic potatoes surrounded the trial and separated the insecticide-treated and untreated blocks.

Tubers from both blocks were hand harvested on 2 to 3 June 1998 in accordance with the field trial approval conditions. Tubers from each plant were collected into separate paper bags. The number of tubers and total weight for each plant was recorded, and the mean weight per tuber was calculated for each plant.

INSECT FEEDING ASSAYS USING FIELD-GROWN FOLIAGE. Natural infestation levels of PTM were too low to provide a measure of the resistance of transgenic lines to PTM larvae, therefore foliage from the lines planted in the insecticide-free area, classified as having phenotypically normal foliage, was used in laboratory bioassays with PTM larvae. Ten neonate larvae were weighed together, and then transferred to a plastic container $(250 \mathrm{~mL})$ containing filter paper (Whatman No. 1,75 mm diameter) along with terminal leaflets from five young fully expanded leaves excised from the field-grown plants. Three containers were used for each potato transgenic line tested, and for each control plot. Lids were placed on each labeled container, which were kept in a laboratory at room temperature $\left(\approx 20^{\circ} \mathrm{C}\right)$ for the duration of the study. The larvae were transferred to freshly excised leaves from a given plot after $5 \mathrm{~d}$. The surviving larvae were weighed individually after $10 \mathrm{~d}$. Following this final weighing, surviving larvae were transferred to fresh leaves from a given plot to determine survival to the adult stage. A GI was calculated for each surviving larva as $\log _{\mathrm{e}}$ (final weight/mean initial weight), where mean initial weight was the mean weight of the ten larvae originally placed into a container.

StaTISTICAL analYsis. The greenhouse GI data were analyzed tributions to the variability in the data (variance components) between the insecticide-treated and untreated blocks (yield data only), plots from the same line (yield data and GI data), or containers from the same plot (GI data only). REML was used because the unequal numbers of plots, plants and surviving larvae for each line made the data unbalanced when all of the variance components were included. However, the variance components for the insecticide-treated and untreated blocks (for the yield data) and plots (for the GI data) were not significant and so could be ignored. This resulted in balanced data sets, allowing ANOVA to be used for the final analysis of the data. The yield data was transformed with logarithms before analysis to make variance

\section{a. Lines derived from Iwa cV.}
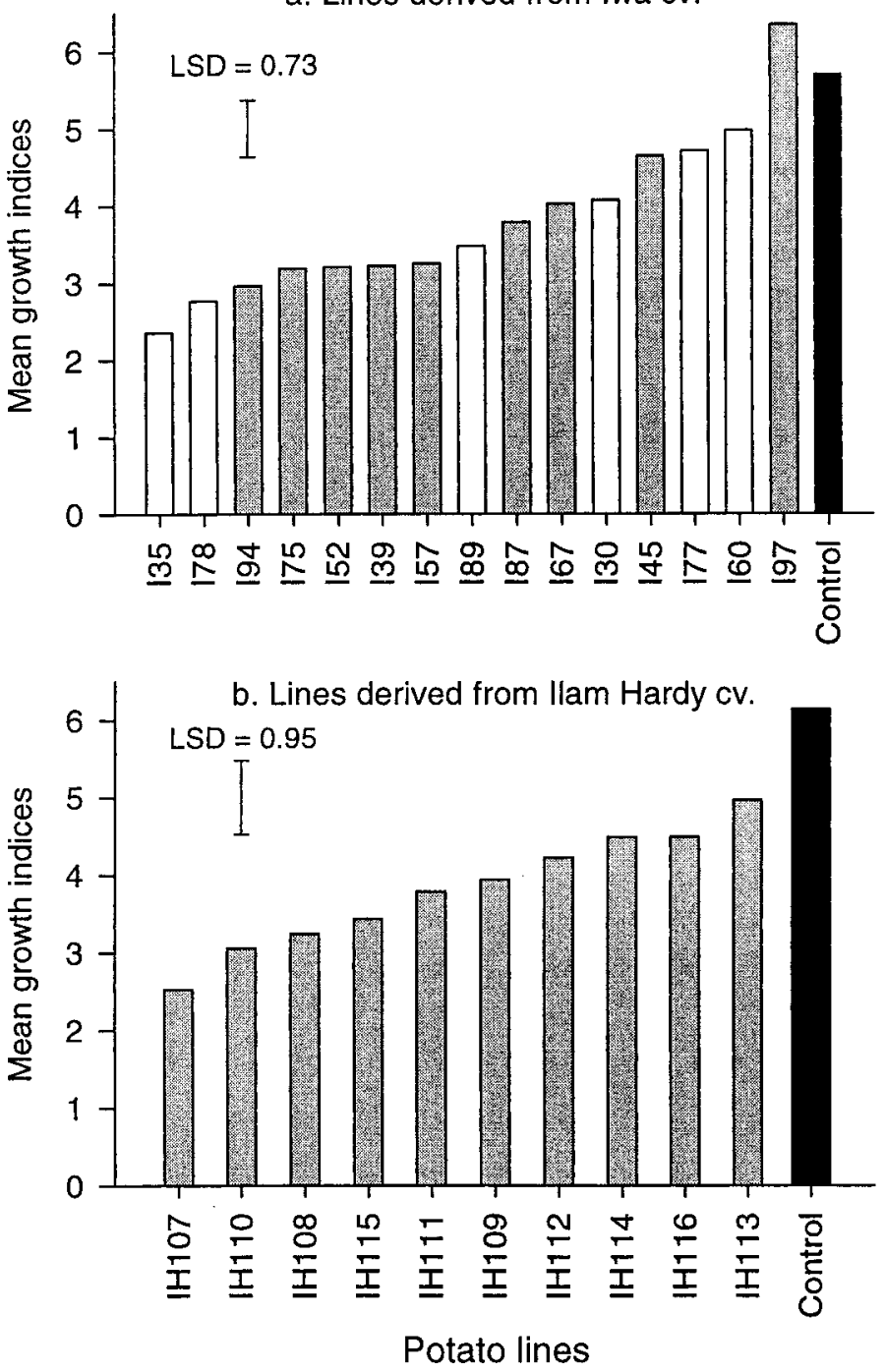

Fig. 2. The mean growth indices $\left[\log _{\mathrm{e}}\right.$ (mean final weight/mean initial weight)] of larvae reared on potato plants derived from (a) Iwa (I) or (b) Ilam Hardy (IH) cultivars, grown in the greenhouse. Bars shaded with grey represent lines with phenotypically normal plants, whereas unshaded bars represent lines with offtype appearance. The LSD is the least significant difference at $P=0.05$ for comparison of each transgenic line with their corresponding control line. 
more homogenous across the lines. All analyses included other transgenic lines not relevant to this study. A level of 5\% was used to determine significance in all analyses, all of which were carried out in Genstat 5 (Genstat Committee, 1997).

\section{Results}

Characterization and greenhouse evaluation of transGENIC POTATO PLANTS. A total of 25 independently derived putative transgenic potato lines were regenerated into complete plants; ten from cultivar Ilam Hardy and 15 from cultivar Iwa. PCR analysis established that all the Ilam Hardy lines were positive for both the nptII gene and the cry gene. The PCR products of selected lines are shown in Fig. 1. All of the Iwa lines were positive for the nptII gene and all but one line (I97) were positive for the cry gene. The amount of Cry protein produced by the transgenic lines was less than $60 \mathrm{ng} \cdot \mathrm{g}^{-1}$ fresh leaf tissue, which represents the detection limit of the ELISA method used.

When grown in the greenhouse, all of the transgenic lines derived from the Ilam Hardy cultivar produced phenotypically

Table 1. The general morphology of transgenic potato lines grown in the field and mean yield variables (back-transformed) measured for each line. There was no significant difference between the data from the insecticide-treated and untreated blocks, therefore the data was pooled. The lines highlighted in bold were not significantly less than the mean control for the three yield variables.

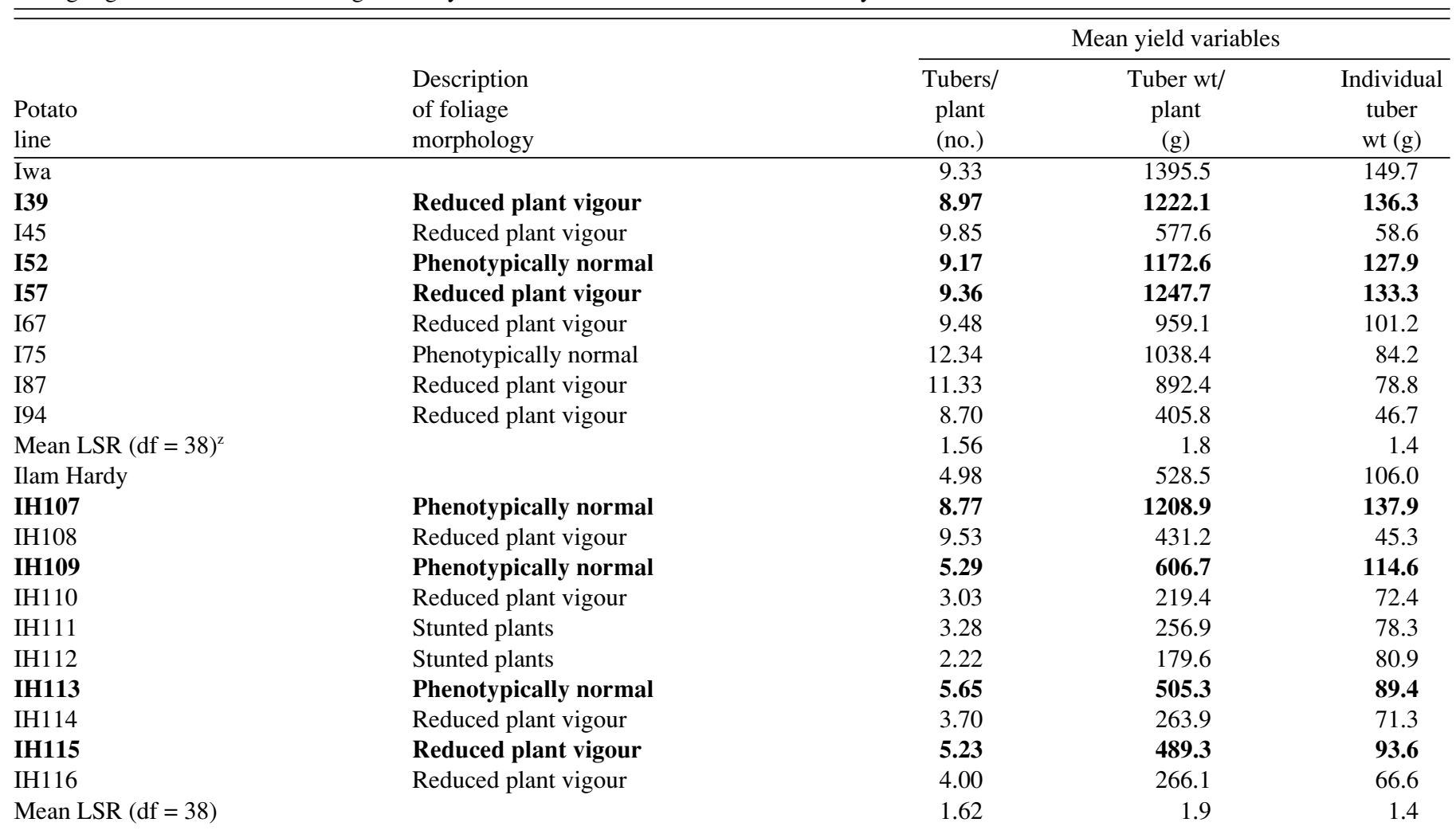

${ }^{\mathrm{Z}} \mathrm{LSR}$ is the least significant ratio, the back-transformed LSD at $P=0.05$ used to compare transgenic yield means with their control yield means for each cultivar. This analysis also included 12 additional potato lines transgenic for a different $c r y$ gene, not related to this study.

Table 2. Development of potato tuber moth reared on foliage from nontransgenic and transgenic potato lines grown in the field trial.

\begin{tabular}{|c|c|c|c|c|c|c|c|}
\hline \multirow{2}{*}{$\begin{array}{l}\text { Potato } \\
\text { line }\end{array}$} & \multirow{2}{*}{$\begin{array}{l}\text { Larval } \\
\text { growth } \\
\text { index }^{y}\end{array}$} & \multirow{2}{*}{$\begin{array}{c}\text { Total } \\
\text { to pupate } \\
\text { (no.) }\end{array}$} & \multicolumn{4}{|c|}{$\begin{array}{l}\text { No. to pupate } \\
\text { by day }\end{array}$} & \multirow{2}{*}{$\begin{array}{c}\text { Adults to } \\
\text { emerge } \\
\text { (no.) }\end{array}$} \\
\hline & & & 10 & 18 & 22 & 29 & \\
\hline $\mathrm{I} 52$ & 2.63 & 1 & --- & --- & --- & 1 & 1 \\
\hline $\mathrm{I} 75$ & 3.38 & 4 & --- & --- & 1 & 3 & 1 \\
\hline $\operatorname{LSD}(\mathrm{df}=40)^{\mathrm{x}}$ & 0.58 & & & & & & \\
\hline IH109 & 3.82 & 8 & --- & --- & 4 & 3 & 5 \\
\hline IH113 & 4.28 & 16 & --- & --- & 11 & 5 & 12 \\
\hline $\operatorname{LSD}(\mathrm{df}=40)$ & 0.67 & & & & & & \\
\hline
\end{tabular}

${ }^{\mathrm{z} F r o m}$ a total of 30 neonate larvae.

yThe larval growth index was calculated as $\log _{e}$ (final weight/mean initial weight).

${ }^{\mathrm{x}} \mathrm{LSD}$ is the least significant difference at $P=0.05$. This analysis also included 12 additional potato lines transgenic for a different $c r y$ gene, not related to this study. 
normal plants and significantly reduced the growth of PTM larvae $(P<0.05$, Fig. 2). All but one (I60) of the Iwa derived transgenic lines positive for the presence of the cry1Ac gene significantly reduced larval growth (Fig. 2). Only eight of the 13 Iwa transgenic lines that inhibited larval growth produced phenotypically normal plants when grown in the greenhouse (Fig. 2).

Field evaluation. The ten Ilam Hardy lines and eight Iwa lines that produced phenotypically normal plants and exhibited improved resistance to PTM larvae when grown in the greenhouse were established in a field trial. Only two of the Iwa (I52 and I75) and three of the Ilam Hardy (IH107, IH109, and IH113) transgenic lines were described as having a phenotypically normal appearance when field-grown. All of the remaining Iwa and five of the Ilam Hardy transgenic lines were described as having reduced vigor (Table 1). The plants of the remaining two Ilam Hardy transgenic lines exhibited severely stunted growth. All of the lines described as phenotypically normal did not yield significantly less than the corresponding controls (Table 1).

Field-grown foliage from the phenotypically normal lines was used in bioassays with PTM larvae. All transgenic lines slowed the development of PTM larvae (Table 2). The transgenic lines I52 and IH107 consistently inhibited larval growth by $\geq 40 \%$. The line IH107 also prevented all larvae from pupating (Table 2). There was a strong correlation between growth indices of larvae fed greenhouse grown foliage and those fed field-grown foliage $(r=0.98$; Fig. 3).

SOUTHERN ANALYSIS. The five high performing transgenic lines identified from the field trial were further characterized via Southern analysis. This further confirmed the transgenic status of these lines and established that they all had either one or two copies of the cry1Ac9 gene (Fig. 4).

\section{Discussion}

Agrobacterium-mediated transformation of potato, based on selection for kanamycin resistance using an nptII selectable marker gene, provided an effective technique for the transfer of a cry $1 \mathrm{Ac} 9$ gene for improved resistance to PTM larvae. PCR

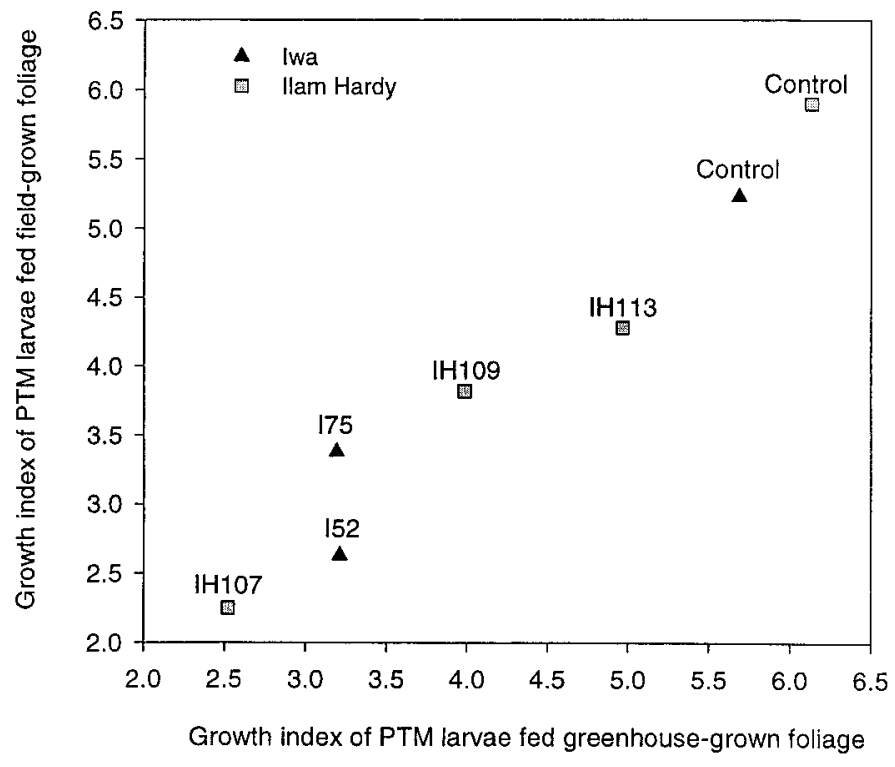

Fig. 3. The correlation between the mean growth indices of larvae fed foliage grown in the greenhouse or field, $r=0.98$. The label nearest a given symbol refers to a particular potato line.

analysis established that all 25 regenerated lines were transgenic for the $n p t I I$ gene, and all but one line (I97) were also positive for the presence of the cry gene. It is possible with line I97 that a rearrangement of the T-DNA occurred upon integration into the potato genome (Deroles and Gardner, 1988), allowing the transfer of the selectable marker gene without the neighboring cry gene. This line therefore provided a useful vector control for the bioassays against PTM larvae. Since 197 did not inhibit larval growth (Fig. 2), we can be confident that the cry1Ac9 gene conferred the resistance observed in all other transgenic lines.

The amount of Cry protein expressed by the transgenic potato lines was below the detection limit of the ELISA method used ( $<60 \mathrm{ng}$ per gram of fresh leaf tissue). Cheng et al. (1992) transformed potato plants with a cry1Ac gene, which were later used for measurements of PTM survival and food consumption on plants from the second tuber-derived generation by Ebora et al. (1994). The Cry protein was not quantified and Ebora et al. (1994) reported only a slight increase in mortality of PTM larvae after $240 \mathrm{~h}$. In this paper we recorded high mortality in several transgenic lines, with $100 \%$ mortality for one line after $240 \mathrm{~h} \mathrm{(10}$ d, Table 2).

Potato plants transgenic for resistance to PTM larvae using a cry1Ab gene have also been developed (Jansens et al., 1995; Cañedo et al., 1997). Some of these transgenic potato lines induced $100 \%$ mortality after $10 \mathrm{~d}$. ELISA quantification of the Cry protein in these lines resulted in levels from 1.9 to 10.9 $\mathrm{ng} \cdot \mathrm{mg}^{-1}$ of soluble protein. Overall these results suggest a lower protein expression from the cry $1 \mathrm{Ac}$ gene relative to cry $1 \mathrm{Ab}$ gene in transgenic potato plants, which still resulted in similar levels of resistance to PTM larvae. Benedict et al. (1992) reported a similar result for cotton transgenic for cry $1 \mathrm{Ab}$ or cry $1 \mathrm{Ac}$. The cry $1 \mathrm{Ab}$ transgenic lines expressed up to $0.35 \%$ of total soluble protein, while a cry $1 \mathrm{Ac}$ gene was expressed at a maximum of only $0.056 \%$ of total soluble protein. Despite this difference in protein expression, transgenic lines with either of these genes exhibited similar levels of resistance to lepidopteran pests.

A cry1Ia1 gene, previously known as cryV (Crickmore et al., 1998 ) and derived from $B$. thuringiensis var. kurstaki was trans-

5275 Iwa IH 107113109

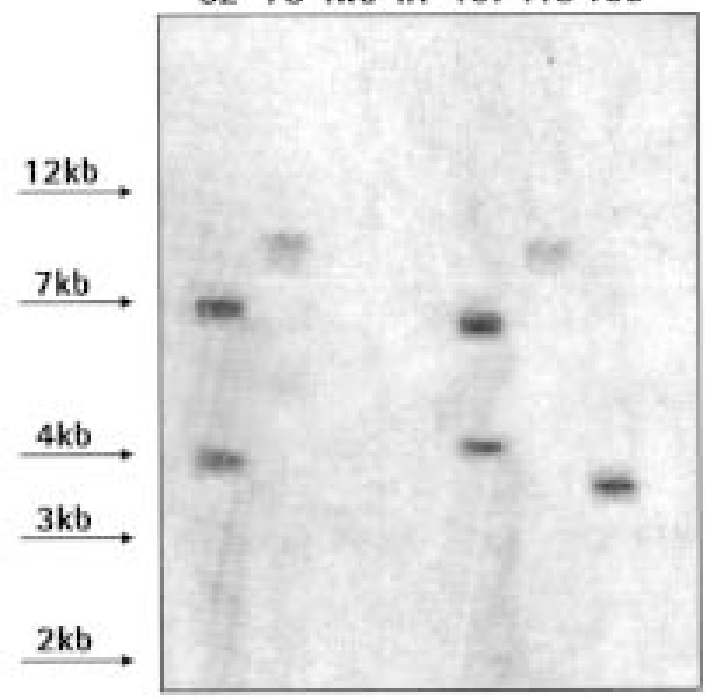

Fig. 4. Southern analysis of the phenotypically normal field-grown transgenic lines and their corresponding parental cultivar, Iwa or Ilam Hardy (IH). DNA was restricted with the HindIII and probed with the chimeric cry gene. A single band greater than $3.69 \mathrm{~kb}$ is expected for each intact insertion of the chimeric cry gene. 
formed into potato, and caused $100 \%$ mortality of PTM larvae fed transgenic leaf or tuber tissue (Li et al., 1999; Mohammed et al., 2000). All PTM larvae fed transgenic leaf tissue were killed after $5 \mathrm{~d}$ (Li et al., 1999) or within three weeks when reared on transgenic tubers (Mohammed et al., 2000). The foliage of potato plants transgenic for cry1Ia1 would appear to be more toxic than cry $1 \mathrm{Ab}$ or cry $1 \mathrm{Ac}$, either through a higher expression of the Cry protein or because PTM larvae are more susceptible to cry1Ia1. Cry1Ia1 is also active against Coleoptera (Douches et al., 1998), while $c r y 1 \mathrm{Ab}$ and $c r y 1 \mathrm{Ac}$ are specific to Lepidoptera.

In this study, transgenic potato lines that significantly inhibited larval growth were considered to have increased resistance to PTM. However, the independently derived transgenic lines varied in the level of resistance to PTM larvae (Fig. 2). This variability in resistance has been repeatedly reported in other studies developing transgenic plants resistant to insect pests (Peferoen et al., 1990; Perlak et al., 1993; Van Rie et al., 1994; Jansens et al., 1995; Li et al., 1999; Beuning et al., 2001). Such variation in the magnitude of transgene expression is typical among populations of plants independently transformed with the same transgene. This unpredictable expression is usually attributed to position effects resulting from the random integration of transgenes into different sites of plant genomes (Conner and Christey 1994). The number of insertion events in each transgenic line has also been implicated in this variation in expression, where the number of copies can be positively or negatively correlated with transgene expression (Hobbs et al., 1993). Of the five highperforming lines identified in this study, Southern analysis established that the two most resistant lines (I52 and IH107) had two copies of the cry gene, whereas the remaining lines had only single copies (Fig. 4).

The appearance of phenotypically abnormal plants is typically observed among populations of transgenic plants (Conner and Christey, 1994; Veilleux and Johnson, 1998), and has been commonly reported in potato (Dale and McPartlan, 1992; Jongedijk et al., 1992; Belknap et al., 1994; Conner et al., 1994). These offtypes are predominantly attributed to the occurrence of somaclonal variation, which involves epigenetic or genetic changes during the cell culture and shoot regeneration phase of plant transformation (Conner and Christey, 1994). A high frequency of off-types among the transgenic lines was apparent in this study. Six of the fifteen transgenic lines from cultivar Iwa exhibited an off-type appearance in the greenhouse (Fig. 2). Although the remaining Iwa lines and all ten Ilam Hardy lines had phenotypically normal appearance when grown in the greenhouse (Fig. 2), the majority had abnormal phenotypic appearance and/or reduced yield when grown in the field (Table 1). This confirms earlier observations that the incidence of somaclonal variation among transgenic potato lines becomes more evident under the fluctuating environmental conditions associated with field trials (Conner et al., 1994).

The bioassay methods used to screen the transgenic lines were effective at identifying those with improved resistance to larvae of PTM. Even though the less resistant lines (higher larval growth indices) delayed development of larvae (Table 2), some PTM were still able to pupate. The growth index therefore provides an effective means of screening transgenic lines to identify the small number of lines with the desired level of resistance. A similar delay in development coupled with low mortality of PTM larvae has been recorded for transgenic potatoes expressing cry $1 \mathrm{Ab}$ (Jansens et al., 1995) and cry1Ia1 (Mohammed et al., 2000) genes.
The strong correlation between the larval growth indices obtained from the greenhouse bioassays and field trial bioassays (Fig. 3) suggest the difference in bioassay technique did not impact on the results. Greenhouse experiments are therefore important in identifying resistant lines, but field trials are essential for identifying high performing transgenic potato lines with good transgene expression, phenotypic appearance and yield equal to that of the parent cultivar. This study has succeeded in developing a series of potato lines transgenic for a cry 1 Ac9 gene and in identifying lines from two cultivars with high performance. Lines IH107 and I52 retained comparable phenotypic appearance and yield to their parent cultivars coupled with high resistance to PTM.

\section{Literature Cited}

Belknap, W.R., D. Corsini, J.J. Pavek, G.W. Snyder, D.R. Rockhold, and M.E. Vayda. 1994. Field performance of transgenic Russet Burbank and Lemhi Russet potatoes. Amer. Pot. J. 71:285-296.

Benedict, J.H., E.S. Sachs, D.W. Altman, W.R. Deaton, R.J. Kohel, D.R. Ring, and S.A. Berberich. 1992. Field performance of cotton expressing transgenic CryIA insecticidal proteins for resistance to Heliothis virescens and Helicoverpa zea (Lepidoptera: Noctuidae). J. Econ. Entomol. 89:230-238.

Beuning, L.L., D.S. Mitra, N.P. Markwick, and A.P. Gleave. 2001. Minor modifications to the cry 1 Ac9 nucleotide sequence are sufficient to generate transgenic plants resistant to Phthorimaea operculella. Ann. Appl. Biol. 138:281-292.

Bernatzky, R and S.D. Tanksley. 1986. Genetics of actin-related sequences in tomato. Theor. Appl. Genet. 72:314-339.

Cañedo, V., J. Benavides, A. Golmirzaie, F. Cisneros, M. Ghislain, and A. Lagnaoui. 1997. Assessing Bt-transformed potatoes for potato tuber moth , Phthorimaea opercullela (Zeller) management, p. 161-170. Program Report 1997-98: Impact on a changing world. International Potato Centre (CIP), Lima.

Chavez, R., P.E. Schmiediche, M.T. Jackson, and K.V. Raman. 1989. The breeding potential of wild potato species resistant to the potato tuber moth, Phthorimaea operculella (Zeller). Euphytica 39:123-132.

Cheng, J., M.G. Bolyard, R.C. Saxena, and M.B. Sticklen. 1992. Production of insect resistant potato by genetic transformation with a dendotoxin gene from Bacillus thuringiensis var. kurstaki. Plant Sci. 81:83-91.

Conner, A .J. and M.C. Christey. 1994. Plant breeding and seed marketing options for introduction of transgenic insect-resistant crops. Biocon. Sci. Tech. 4:463-473.

Conner, A. J., M.K. Williams, D.J Abernethy, P.J. Fletcher, and R.A Genet. 1994. Field performance of transgenic potatoes. N.Z. J. Crop. Hort. Sci. 22:361-371.

Crickmore, N., D.R. Zeigler, J. Feitelson, E. Schnepf, J. van Rie, D. Lereclus, J. Baum, and D.H. Dean. 1998. Revision of the nomenclature for the Bacillus thuringiensis pesticidal crystal proteins. Microbio. Mol. Biol. Rev. 62:807-813.

Dale, P.J. and H.C McPartlan. 1992. Field performance of transgenic potato plants compared with controls regenerated from tuber discs and shoot cuttings. Theor. Appl. Genet. 84:585-591.

Deroles, S.C. and R.C. Gardner. 1988. Analysis of the T-DNA structure in a large number of transgenic petunias generated by Agrobacteriummediated transformation. Plant Mol. Biol. 11:365-377.

Douches, D.S., A.L. Westedt, K.A. Zarka, B. Schroeter, and E.J. Grafius. 1998. Potato transformation to combine natural and engineered resistance for controlling tuber moth. HortScience 33:1053-1056.

Ebora, R.V., M.M. Ebora, and M.B. Sticklen. 1994. Transgenic potato expressing the Bacillus thuringiensis cryIA(c) gene effects on the survival and food consumption of Phthorimaea operculella (Lepidoptera: Gelechiidae) and Ostrinia nubilalis (Lepidoptera: Noctuidae). J. Econ. Entomol. 87:1122-1127.

Fenemore, P.G. 1980. Susceptiblity of potato cultivars to potato tuber 
moth, Phthorimaea operculella, Zell. (Lepidoptera: Gelechiidae). N.Z J. Agr. Res. 23: 539-546.

Foot, M.A. 1979. Bionomics of the potato tuber moth, Phthorimaea operculella (Lepidoptera: Gelechiidae), at Pukekohoe. N.Z. J. Zool. 6:623-636.

Genstat Committee. 1997. Genstat 5 Release 4.1. Reference Manual Supplement. Numerical Algorithms Group Ltd., Oxford.

Gilmour, A.R., R. Thompson, and B.R. Cullis. 1995. Average Information REML, an efficient algorithm for variance parameter estimation in linear mixed models. Biometrics 51:1440-1450.

Gleave, A.P. 1992. A versatile binary vector system with a T-DNA organizational structure conducive to efficient integration of cloned DNA into the plant genome. Plant Mol. Biol. 20:1203-1207.

Gleave, A.P., R.J. Hedges, A.H. Broadwell, and P.J. Wigley. 1992. Cloning and nucleotide sequence of an insecticidal crystal protein gene from Bacillus thuringiensis DSIR732 active against three species of leafroller (Lepidoptera: Tortricidae). N.Z. J. Crop Hort. Sci. 20:27-36.

Hobbs, S.L.A., T.D. Warkentin, and DeLong C.M.O. 1993. Transgene copy number can be positively or negatively associated with transgene expression. Plant Mol. Biol. 15:17-26.

Hoekema, A., P.R. Hirsch, P.J.J. Hooykaas, and R.A. Schilperoort. 1983. A binary plant vector strategy based on separation of vir- and T-region of the Agrobacterium tumefaciens Ti-plasmid. Nature 303:179-180.

Jansens, S., M. M. Cornelissen, R. de Clercq, A. Reynaerts, and M. Peferoen. 1995. Phthorimaea operculella (Lepidoptera: Gelechiidae) resistance in potato by expression of the Bacillus thuringiensis cryIA(b) insecticidal crystal protein. J. Econ. Entomol. 88:1469-1476.

Jongedijk, E., A.A.J.M. de Schutter, P.J.M. van-den Elzen, and B.J.C. Cornelissen. 1992. Increased resistance to potato virus X and preservation of cultivar properties in transgenic potatoes under field conditions. Bio/Technology 10:422-429.

Li, W.B., K.A. Zarka, D.S. Douches, J.J. Coombs, W.L. Pett, and E.J. Grafius. 1999: Coexpression of potato $\mathrm{PVY}^{\circ}$ coat protein and $c r y \mathrm{~V}-\mathrm{Bt}$ genes in potato. J. Amer. Soc. Hort. Sci. 124:218-223.

Mohammed, A., D.S. Douches, W. Pett, E. Grafius, J. Coombs,
Liswidowati, W. Li, and M.A. Madkour. 2000. Evaluation of potato tuber moth (Lepidoptera: Gelechiidae) resistance in tubers of Bt-cry5 transgenic potato lines. J. Econ. Entomol. 93:472-476.

Murashige, T. and F. Skoog. 1962. A revised medium for rapid growth and bioassays with tobacco tissue cultures. Physiol. Plant. 15:473-497.

Oatman, E.R. and G.R. Platner. 1974. Parasitization of the potato tuberworm in Southern California. Environ. Entomol. 3:262-265.

Ortiz, R., M. Iwanaga, K.V. Raman, and M. Palacios. 1989. Breeding for resistance to potato tuber moth, Phthorimaea operculella (Zeller), in diploid potatoes. Euphytica 50:119-125.

Peferoen, M., S. Jansens, A. Reynaerts, and J. Leemans. 1990. Potato plants with engineered resistance against insect attack, p. 193-204. In: W.R. Belknap, M.E. Vayda, and W.D. Park (eds.). The molecular and cellular biology of the potato. CAB Intl. Wallingford.

Perlak, F.J., T.B. Stone, Y.M. Muskopf, L.J. Petersen, G.B. Parker, S.A. McPherson, J. Wyman, S. Love, G. Reed, D. Biever, and D.A. Fischhoff. 1993. Genetically improved potatoes: protection from damage by Colorado potato beetles. Plant Mol. Biol. 22:313-321.

Plaisted, R.L., M.W. Bonierbale, G.C. Yencho, O. Pineda, W.M. Tingey, J. van den Berg, E.E. Ewing, and B.B. Brodie. 1994. Potato improvement by traditional breeding and opportunities for new technologies, $p$. 1-20. In: W.R. Belknap, M.E. Vayda, and W.D. Park (eds.). The molecular and cellular biology of the potato. CAB Intl. Wallingford.

Raman, K.V. and M. Palacios. 1982. Screening potato for resistance to potato tuberworm. Entomol. Soc. Amer. 75:47-49.

Siddig, S.A. 1988. Cultural means of controlling potato tuber moth (Phthorimaea operculella Zell) and improvement of potato yield and quality in the Sudan. Acta Hort./Trop. Hort. 218/XII:281-288.

Van Rie, J., S. Jansens, and A. Reynaerts. 1994. Engineered resistance against potato tuber moth, p. 499-507. In: G.W. Zehnder, M.L. Powelson, R.K. Jansson, and K.V. Raman (eds.). Advances in potato pest biology and management. APS Press, St. Paul, Minnesota.

Veilleux, R.E. and A.A.T. Johnson. 1998. Somaclonal variation: molecular analysis, transformation interaction, and utilization. Plant Breeding Rev. 16:229-268. 